\title{
Familial Lipomas Without Classic Neurofibromatosis-1 Caused by a Missense Germline NF1 Mutation
}

Erika Ramirez, BSN, Stephanie M. Morris, MD, Tychele N. Turner, PhD, and David H. Gutmann, MD, PhD

Neurol Genet 2021;7:e582. doi:10.1212/NXG.0000000000000582
Correspondence

Dr. Gutmann

gutmannd@wustl.edu

Neurofibromatosis type 1 (NF1; OMIM 162200) is an autosomal dominant disorder caused by a wide variety of germline mutations in the NF1 gene. Nearly all individuals with NF1 exhibit café-au-lait macules before the age of $2,{ }^{1}$ but can also develop numerous other medical problems, including autism, cognitive deficits, tumors, and congenital heart defects. Although the clinical variability inherent in NF1 has been attributed to stochastic events, it is possible that the specific germline NF1 mutation might be one factor underlying this heterogeneity. To illustrate this point, we report a family with 2 affected members harboring a missense mutation in the NF1 gene who lack the classic features of NF1.

The proband came to medical attention for failure to thrive, hypotonia, global delay, projectile vomiting, and feeding problems, necessitating the placement of a gastrostomy tube at 9 months of age. Although the pregnancy and vaginal delivery at 39 weeks of gestation were uncomplicated, soon after birth, a patent foramen ovale and pulmonic valve stenosis were noted. Because her father had several cutaneous masses, later pathologically determined to be lipomas, the patient underwent chromosomal microarray (normal) and NF1 genetic testing, revealing a c.3445A $>\mathrm{G}$ (p.Met1149Val) germline mutation in the NF1 gene, which was paternally inherited based on parental NF1 genetic testing. Her father had no Lisch nodules, café-au-lait macules, or skinfold freckling. The patient also had no caféau-lait macules or skinfold freckling at 20 months of age, but had 2 mobile subcutaneous nodular masses on her left chest, suggestive of neurofibromas. No plexiform neurofibromas were appreciated on either the patient or her father, and no other members of their extended family had features of NF1. The patient underwent brain and total spine neuroimaging, based on a left-hand preference, axial hypotonia and a reluctance to bear weight on her legs, which were completely normal.

The finding of a germline NF1 mutation in this family raises several important points. First, this missense mutation results in a methionine to valine change in an amino acid residue conserved in vertebrates and flies and predicted to be pathogenic using both PolyPhen (isoform-1, possibly damaging, 0.557; isoform-2, probably_damaging, 0.909) and SIFT (both isoforms, deleterious, 0) variant pathogenicity analysis programs. Of interest, the mutated amino acid is $5^{\prime}$ to the RAS GTPase activating protein-related domain and is located within a segment involved in tubulin binding and neurofibromin homodimerization (residues $1,085-1,172) .^{2}$ This variant has a frequency of 1 in 251,376 alleles in control individuals ( 0.000003978 ; gnomAD database). It has also been reported in a 56-year-old woman with malignant melanoma whose tumor harbored both the Met1149Val mutation and another NF1 mutation, creating a premature protein truncation (Leu1109X) within the same domain and resulting in $5 \%$ of normal NF1 gene expression (cBioPortal). ${ }^{3}$ For these reasons, it is highly likely that the Met1149Val mutation is pathogenic in this family.

Second, although this family did not have NF1, patients with NF1 and Met1149Val NF1 gene mutations tend to exhibit a mild clinical phenotype, with a paucity of optic gliomas or plexiform neurofibromas. ${ }^{4}$ In contrast to the family reported herein, of the 48 patients with clinical assessments, ${ }^{4}$ $94 \%$ had greater than 5 café-au-lait macules: Only 2 of these individuals had lipomas, and only 1 had

From the Department of Neurology (E.R., S.M.M., D.H.G.) and Department of Genetics (T.N.T.), Washington University School of Medicine, St. Louis, MO.

Go to Neurology.org/NG for full disclosures. Funding information is provided at the end of the article.

The Article Processing Charge was funded by the National Institutes of Health.

This is an open access article distributed under the terms of the Creative Commons Attribution-NonCommercial-NoDerivatives License 4.0 (CC BY-NC-ND), which permits downloading and sharing the work provided it is properly cited. The work cannot be changed in any way or used commercially without permission from the journal. 
pulmonic stenosis. The finding of this mutation in a family without NF1 extends the spectrum of clinical manifestations that likely arise from Met1149Val mutation.

Third, the lack of classic features of NF1 in these 2 individuals add to the growing list of specific genotype-phenotype correlations in patients with NF1, including patients harboring Arg1809 missense and Met991 codon deletion mutations who do not develop optic gliomas or neurofibromas. ${ }^{4}$ Similarly, patients with missense mutations located in residues spanning 844 to 848 have been reported to exhibit more severe disease complications. ${ }^{5}$ As the differential effects of specific germline NF1 gene mutations become elucidated, it is possible that they will help to define specific contact points for neurofibromin binding partners that underlie these unique effects.

Finally, previous work from our laboratory has shown that different germline NF1 gene mutations create dissimilar biological effects. Using human-induced pluripotent stem cells and mice genetically engineered with NF1 patient NF1 gene mutations, we found striking differences in neuronal differentiation ${ }^{6}$ and optic glioma formation. ${ }^{7}$ Surprisingly, this variability was not the result of different levels of RAS hyperactivation, but rather reflected other functions of neurofibromin, some of which remain to be defined. These observations suggest that other readouts for neurofibromin activity, besides RAS pathway signaling, are needed to characterize the contributions of different germline NF1 gene mutations to human disease pathobiology.

\section{Study Funding}

This work was supported by a Research Program Award grant from the National Institutes of Health (1-R35-NS07211-01 to D.H.G).

\section{Disclosure}

D.H. Gutmann has a licensing agreement with the Tuberous Sclerosis Alliance (GFAP-Cre mice). The other authors have no relevant conflicts of interest to disclose. Full disclosure form information provided by the authors is available with the full text of this article at Neurology.org/NG.

\section{Publication History}

Received by Neurology: Genetics January 21, 2021. Accepted in final form February 23, 2021.

\section{Appendix Authors}

\begin{tabular}{|c|c|c|}
\hline Name & Location & Contribution \\
\hline $\begin{array}{l}\text { Erika } \\
\text { Ramirez, } \\
\text { BSN }\end{array}$ & $\begin{array}{l}\text { Department of Neurology, } \\
\text { Washington University School } \\
\text { of Medicine, St. Louis, MO }\end{array}$ & $\begin{array}{l}\text { Major role in the } \\
\text { acquisition of data and } \\
\text { analysis or interpretation } \\
\text { of data }\end{array}$ \\
\hline $\begin{array}{l}\text { Stephanie } \\
\text { M. Morris, } \\
\text { MD }\end{array}$ & $\begin{array}{l}\text { Department of Neurology, } \\
\text { Washington University School } \\
\text { of Medicine, St. Louis, MO }\end{array}$ & $\begin{array}{l}\text { Drafting/revision of } \\
\text { the manuscript for } \\
\text { content, including } \\
\text { medical writing for } \\
\text { content }\end{array}$ \\
\hline $\begin{array}{l}\text { Tychele N. } \\
\text { Turner, } \\
\text { PhD }\end{array}$ & $\begin{array}{l}\text { Department of Genetics, } \\
\text { Washington University School } \\
\text { of Medicine, St. Louis, MO }\end{array}$ & $\begin{array}{l}\text { Drafting/revision of } \\
\text { the manuscript for } \\
\text { content, including } \\
\text { medical writing } \\
\text { for content, and } \\
\text { analysis or interpretation } \\
\text { of data }\end{array}$ \\
\hline $\begin{array}{l}\text { David H. } \\
\text { Gutmann, } \\
\text { MD, PhD }\end{array}$ & $\begin{array}{l}\text { Department of Neurology, } \\
\text { Washington University School } \\
\text { of Medicine, St. Louis, MO }\end{array}$ & $\begin{array}{l}\text { Drafting/revision of } \\
\text { the manuscript for } \\
\text { content, including } \\
\text { medical writing for } \\
\text { content, major role } \\
\text { in the acquisition } \\
\text { of data, study concept } \\
\text { or design, and } \\
\text { analysis or } \\
\text { interpretation } \\
\text { of data }\end{array}$ \\
\hline
\end{tabular}

\section{References}

1. Nunley KS, Gao F, Albers AC, Bayliss SJ, Gutmann DH. Predictive value of cafe au lait macules at initial consultation in the diagnosis of neurofibromatosis type 1. Arch Dermatol 2009;145:883-887.

2. Sherekar M, Han SW, Ghirlando R, et al. Biochemical and structural analyses reveal that the tumor suppressor neurofibromin (NF1) forms a high-affinity dimer. J Biol Chem 2020;295:1105-1119.

3. Gao J, Aksoy BA, Dogrusoz U, et al. Integrative analysis of complex cancer genomics and clinical profiles using the cBioPortal. Sci Signal 2013;6:pl1

4. Koczkowska M, Callens $\mathrm{T}$, Chen $\mathrm{Y}$, et al. Clinical spectrum of individuals with pathogenic NF1 missense variants affecting p.Met1149, p.Arg1276, and p.Lys1423: genotype-phenotype study in neurofibromatosis type 1. Hum Mutat 2020;41: 299-315.

5. Koczkowska M, Chen Y, Callens T, et al. Genotype-phenotype correlation in NF1: evidence for a more severe phenotype Associated with missense mutations affecting NF1 codons 844-848. Am J Hum Genet 2018;102:69-87.

6. Anastasaki C, Wegscheid ML, Hartigan K, et al. Human iPSC-derived neurons and cerebral organoids establish differential effects of germline NF1 gene mutations. Stem Cel Rep 2020;14:541-550.

7. Guo X, Pan Y, Gutmann DH. Genetic and genomic alterations differentially dictate low-grade glioma growth through cancer stem cell-specific chemokine recruitment of $\mathrm{T}$ cells and microglia. Neuro Oncol 2019;21:1250-1262. 


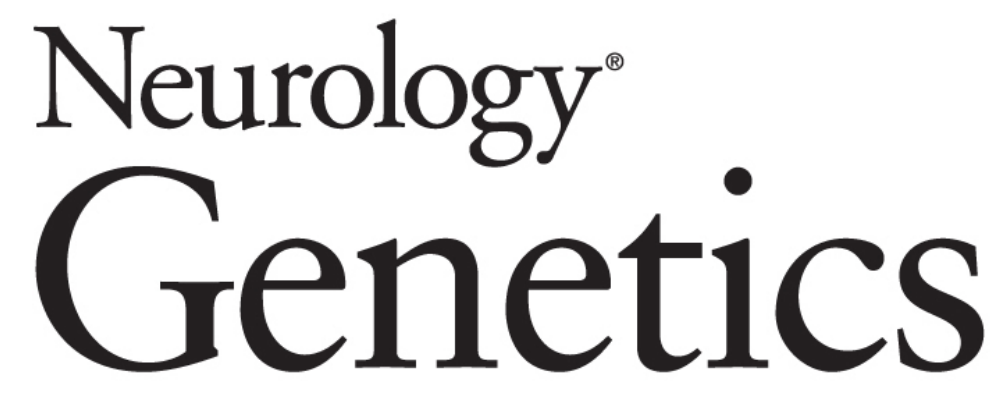

\section{Familial Lipomas Without Classic Neurofibromatosis-1 Caused by a Missense Germline NF1 Mutation}

Erika Ramirez, Stephanie M. Morris, Tychele N. Turner, et al. Neurol Genet 2021;7;

DOI 10.1212/NXG.0000000000000582

\section{This information is current as of March 26, 2021}

\section{Updated Information \&} Services

\section{References}

Subspecialty Collections

Permissions \& Licensing

Reprints including high resolution figures, can be found at: http://ng.neurology.org/content/7/3/e582.full.html

This article cites 7 articles, 2 of which you can access for free at: http://ng.neurology.org/content/7/3/e582.full.html\#\#ref-list-1

This article, along with others on similar topics, appears in the following collection(s):

Neurofibromatosis

http://ng.neurology.org//cgi/collection/neurofibromatosis

Other neurocutaneous disorders

http://ng.neurology.org//cgi/collection/other_neurocutaneous_disorders

Information about reproducing this article in parts (figures,tables) or in its entirety can be found online at:

http://ng.neurology.org/misc/about.xhtml\#permissions

Information about ordering reprints can be found online: http://ng.neurology.org/misc/addir.xhtml\#reprintsus

Neurol Genet is an official journal of the American Academy of Neurology. Published since April 2015, it is an open-access, online-only, continuous publication journal. Copyright Copyright $\odot 2021$ The Author(s). Published by Wolters Kluwer Health, Inc. on behalf of the American Academy of Neurology.. All rights reserved. Online ISSN: 2376-7839.

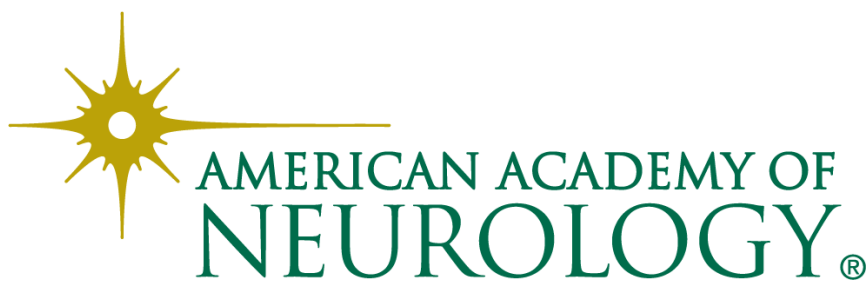

